\title{
Педагогические проблемы развития готовности к самореализации у старшеклассников
}

Готовность к самореализации является существенным компонентом личностного развития и уровень ее сформированности оказывает существенное влияние на особенности самоопределения старшеклассников на этапе окончания школы. Направленное дидактическое сопровождение по формированию ценностно-смысловых ориентаций старшеклассников влияет на особенности формирования их смысложизненных стратегий, личностных перспектив и готовности к самореализации. В данной статье выявляется дидактический потенциал формирования готовности к самореализации старшеклассников с точки зрения смыслодидактического подхода.

Ключевые слова: педагогическое сопровождение, ченностно-смыслово сфера личности, технологии направленного воздействия в учебном прочессе смыслодидактика.

Принципиальные изменения в российском обществе, «носящие, по млы, характер цивилизационного слома, качественно преобразили все сторон че), вєческой жизни - демографическую, этнополитическую, технологическую, ¿qиальную, экономическую, обусловив новую культурно-историческую Ииуа иию нашего бытия» (Д.И. Фельдштейн). Новые условия потребуют от каждрю мөлодого человека поиска новых нестандартных индивидуальных вариантов построения своей жизни. В связи с новыми приоритетами в общественном раз зи особо перспективной становится проблема личностной самореализации п-кольку наиболее полное раскрытие способностей человека возможна пи м в общественно значимой деятельности, а именно готовность к саморео (1) зации является залогом ее выполнения на высоком уровне качества. Пр 1-л важно, чтобы осуществление этой деятельности детерминировалось не тль оизвне (обществом), но и внутренней потребностью самой личности. Дея сер рпость личности в этом случае становится самодеятельностью, а реализаци - особностей в данной деятельности приобретает характер самореализ цим Этому посвящены работы отечественных и западных психологов, рассм рающих смысловую сферу личности и особенности её самореализации: Ив а уумова, А.Ю. Агафонов, А.Г. Асмолов, Д.А. Леонтьев, А. Маслоу, К. Роджер В. Рранкл, Х. Хекхаузен, теории, рассматривающие самоорганизацию и сай реа изацию личности в различных жизненных контекстах: Б.Г. Ананьев, Л УАнциферова, А.Г. Асмолов, А.В. Брушлинский, Ф.Е. Василюк, Л.С. Выготс ии, э.В. Галажинский, В.П. Зинченко, В.Е. Клочко, Л.А. Коростылева, Д.А. Леонтьеь, Маслоу, В.Д. Шадриков, Г. Хакен. С позиций принятой в настоящей время Чу энистической парадигмы главной ценностью образования признается спосо бн сть субъекта к самореализации в профессиональной деятельности в опое Аворческий потенциал личности. Не случайно Концепция модернизации 
российского образования ставит задачу достижения более высокого качества профессионального образования, соответствующего современным требованиям эффективности внедрения инновационных процессов, развития у школьников и студентов стремления к профессиональному совершенствованию, которое предполагает активную реализацию в избранной области профессионально значимых и личностных качеств и способностей, знаний и умений.

Однако дидактический аспект исследования самореализации с точки зрения ее развития как важнейшей характеристики личности, пока еще остается малоизученным. «Смысл образования состоит в развитии субъектности человека, которая реализуется в стремлении к самореализации, свободе, ответственности в принятии решений, восхождении к социокультурным образцам» (Румянцева О.М.). Наблюдается очевидный дефицит исследований по разработке дидактических технологий, которые бы не просто инициировали ситуативные смыслы учащихся а работали бы на формирование устойчивых ценностно-смысловых образовании и в частности помогали на том этапе развития, когда готовность к самореа иза ции во многом предопределяет реализацию смысложизненных страт Гиı. Ряд педагогов и психологов пытаются разрешить данную проблему в рамках н дидактического направления - смыслодидактики. Смыслодидакти а овое направление в теории обучения, основанное на интегративном см ССл вөи подходе. В рамках этого подхода не только раскрываются основные механим инициирую-

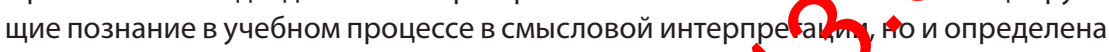
возможность построения целостной модели и систем реe -ерационализации в реальной учебной практике, определяются цели, содержание, технологии, влияющих на формирование смысловой сферы о чаемого, на формирование его смысловой самоориентации и смысложиз ељй концепции. В контексте смысловой парадигмы анализируются как осно ные составляющие классической дидактики: образовательные цели, содержа Avs, методы и формы обучения, так и те дидактические категории, которые २qвляют тезаурус современной теории обучения: обучение как двуединый Пр цесс, главные движущие силы процесса обучения, дидактическое целе толиие, формирование личности, педагогическое сопровождение и под ер (Абакумова И.В., Белова Е.А., Ермаков П.Н., Кагермазова Л.Ц., Рудаков И. ., Фоменко В.Т.).

В данной статье мы рмедтавляем материал по исследованию педагогического сопровождения старшек (алников на этапе формирования готовности к самореализации, которое выл Лн но на основе смыслодидактического подхода. Мы исходили из следующей ии оте для направленного педагогического сопровождения по формирова! ич ненностно-смысловых ориентаций старшеклассников возможно разработап дидактические технологии направленного воздействия, которые будут ини мировать готовность к самореализации, что проявляется в построении и к ९. ктировке поведения, перестройке «концепции Я», включая «идеальное Я», капти ны мира и жизненного плана, осознании результатов предшествующей дея1 бности и рефлексии перспектив будущего (формирование концепции прошлого, 
настоящего, будущего). Дидактический потенциал по формированию готовности к самореализации старшеклассников необходимо реализовывать через дидактическую модель инициации ценностно-смыслового выбора, включающую в себя задачи на смысл, преодоление ценностно-смысловых барьеров и формировании установок позитивного ожидания, которые ставят ученика в позицию смысловой актуализации, когда смысловой след, оставшийся от предшествующего опыта принятия ценностей, из потенциальной формы переходит в актуализированную, сознаваемую и вербализуемую.

Выведение учебного процесса на личностно-смысловой уровень ставит перед педагогической наукой целый ряд проблем, существенной частью которых является переосмысление базовых понятий в ценностно-смысловой интерпретации. Особый блок проблем относится к мотивационно-динамическим компонентам обучения, к переосмыслению уже существующих и разработке новых методов и технологий обучения. Содержанию учебного процесса, которое является полем кристаллизации, питающем смыслообразование и смыслоосознание учащихая должно получить «импульс жизни». Его необходимо как-то расположить в про тр н стве, распределив его между учителем и учащимися, между самими уиащими $A$ и их группами. Его нужно расположить также во времени, дифференцир ав его и наполнив им последовательность процедур действий учителя ича цикся. Это и есть технологические аспектах учебного процесса. Технологии об,ниия предстают как механизм самореализации содержания, и, следовале ьคि, обновляя содержание, в любых его направлениях, включая и смь сообразование, надо адекватным, синхронным образом вносить изменения и в техњологическую культуру. Содержание и технологии оказываются взаимосв 3 - ными органически: если содержание «питает» развитие личности, ее смысло् р бетруктуры, то технологии включают, запускают развитие. Оказавшись неалакь атной содержанию, технология как запускающий инструментарий не «сработае » москольку нарушится принцип изоморфной зависимости содержание - те Нر огия, принцип взаимосоответствия (Абакумова И.В.).

Однако если содержательный On годы все более и более станови ся -ыслонасыщенным, ориентированным на развитие смысловой сферы уиат ном носят или репрезен тиный, или когнитивно-направленный характер. Это противоречие порож а актуальность поиска тех технологий в учебном процессе, которые пс Во, ят вывести его на уровень смысловой саморегуляции через смыслообраз ван и имысловыявление самих учащихся. Такие технологии в новом психо 0 -педагогическом направлении - в смысловой дидактике, называются слютиехнологиями (И.В. Абакумова, П.Н. Ермаков, М.А. Лукьяненко, М.Х. Машеку ева, В.Т. Фоменко).

По хақтеру воздействия на смысловую сферу учащегося смыслотехнологии в учебно И процессе подразделяются на целенаправленные (заданные), ориентироaн. 2 на прямую инициацию смыслообразования и стремящиеся к определенному 
(ожидаемому) эффекту и фасилитирующие (поддерживающие), имеющие целью настолько, насколько это возможно, повысить эффективность соответствующих процессов и устранить ограничивающие их барьеры и блоки через соответствующие смысловые установки, создаваемые преподавателем (по типу так называемая «майевтических» психотехник в психологии и психотерапии).

Опыт современной школы, психолого-дидактические и педагогические исследования показывают необходимость использования сопровождения в обучении, но целостного анализа как именно оно может быть реализовано в соответствие с механизмами смысловой самоактуализации самих учащихся, пока еще нет.

В рамках смысловой дидактики педагогическое сопровождение определяется как создание условий в учебном процессе для естественного, свободного развития личности. Оно направлено на обеспечение беспрепятственного развертывания внутренних, сущностных, универсальных свойств человека. Из такого подход к сопровождению следует, что оно связано с развитием субъекта как психическим новообразованием. К этому классическому пониманию развития как «разв тия субъектности» обращаемся и мы. В смысловой интерпретации на «пси ич ские новообразования» накладываются «смысловые новообразования», виводя, -ким образом, понимание развития за непосредственные пределы психи ес. го: этом случае и традиционные «зоны развития»: зона актуального равимл,зона ближайшего развития, зона саморазвития - могут быть интерпретирады как зоны смыслового развития (точнее сказать, «и смыслового разв тил), для понимания подлинного значения педагогического сопровожденил данше обстоятельство является существенным.

Если «зона ближайшего развития» справедлив (P)сматривается как механизм развития личности, в том числе ее смыслового о ра, и внимание к ней в последнее время повышено, то поддержку как- х холого-дидактическое действие, ориентированное на достигнутый ребенко У,овень развития, следует рассматривать как шаг «назад», как уступку «з следовательно, и смысловую состав Яящую.

Сопровождение следует рас см мливать сдвинутой не в сторону «зоны актуального развития», а в сторон «- саморазвития». Поддержка учащихся - это поддержка их на уровне сам развития, в нашем контексте - «смыслового саморазвития». Чтобы осущ/ Тился акт смыслообразования, необходимы условия, «поддерживающие» эя (роцесс на уровне «данности». Следует, естественно, иметь в виду и то, То зона саморазвития» - не что иное, как «зона актуального развития» в след) нщ м цикле (диалектическом этапе) развития личности.

Интерпр Тлия педагогического сопровождения через «смысловое развитие» снимает ро иооречие между «поддерживающей» и «развивающей» психологией, «поддерж мащей» и «развивающей» педагогикой и дает возможность шире испол 3 вать именно эту технологию в реальной практике учебного процесса.

И следование особенностей педагогического сопровождения по формированию ᄀ Твности к самореализации у старшеклассников включало несколько этапов: 
1) на диагностическом этапе (2008) определены основные направления исследования, сформулированы его цель, задачи и гипотезы; проведен теоретический анализ литературы по проблеме педагогической поддержки и сопровождения формирования личностных особенностей старшеклассников; подобраны и разработаны диагностирующие и формирующие методики, проведен констатирующий эксперимент;

2) на экспериментальном этапе (2009) организован и проведен формирующий эксперимент: апробирован разработанный комплекс методов и реализована система психолого-педагогического сопровождения процесса обучения старшеклассников и учащихся медицинского колледжа на протяжении двух лет обучения;

3) на обобщающем этапе (2010) обобщены и систематизированы результаты опытно-экспериментальной работы по реализации системы педагогической поддержки учащихся с разным уровнем готовности к самореализации, разработаны практические рекомендации для педагогов и школьных психологов.

Процесс опытно-экспериментальной работы включал поисково-теоретичесқц констатирующий, формирующий этапы, каждый из которых имел свои особен Іоси В ходе опытно-экспериментальной работы выделены группы учащихсядмеюц х затруднения в процессе самореализации: 1) сформированное ценност Оө ношение при низких показателях основных компонентов личность й олиреализации; 2) недостаточно сформированное ценностное самоотношени.ри низких

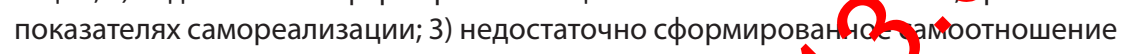
при средних показателях самореализации.

Помимо этого обучаемым оказывалась целенаправленная психологическая помощь в решении проблем мотивации, самоотнощя, представления о перспективных направлениях саморазвития, что поз 10 разрешить вскрытые противоречия и обеспечить успешную саморегли аци.

Проведённая опытно-экспериментальная ра ба свидетельствует об эффективности использования дидактической мод 7,0 ормирования готовности старшеклассников к продуктивной самореали ац. и:Апробация программы подтвердила необходимость и возможность стияу мования процесса самореализации старшеклассника посредством форми о -ия ценностного отношения к собственной личности через учёт в целостио, Зоспитательно-образовательном пространстве образовательной среды пмчнстно значимых потребностей старшеклассника; характера его ценностно С Сиоотношения в процессе приобщения к общечеловеческим ценностям (ри глублённом изучении предметов культурологической направленности; юе леливной самооценочной деятельности старшеклассника в процессе инт Ф,оизации оценочной функции; адекватного уровня притязаний школьников йудентов в процессе постепенной передачи функции планирования индивидуаль й смысложизненной стратегии.

Вь А в особенности сущности, путей и особенностей самореализации личности с аршеклассников, установив объективные и субъективные факторы, 10. 2. ствующих ее свободному развитию и реализации творческого потенциала, 
мы разработали систему методических рекомендаций для педагогов и школьных психологов по использованию дидактической модели формирования готовности к самореализации в массовом педагогическом опыте, которые, по нашему мнению, должны включать следующие составляющие: предъявление учителем учебного содержания подлежащим освоению - соотнесение учеником элементов учебного содержания с собственным информационным фондом - понимание учеником учебного содержания - соотнесение ценностных характеристик учителя с собственной системой ценностей - соотнесение ценностей учебного содержания с собственными ценностями - рассогласование между ценностями предлагаемым для личностного принятия и системы личностных ценностей самого ученикаформирование учителем аттракции - принятие учеником ценностных центраций, презентируемых учителем в осваиваемом учебном содержании завершение убеждающего воздействия как соотнесение учеником ценностей учебного со держания с собственной системой ценностей («синхронизация смысловых попюй» учителя и ученика).

\section{Литература}

1. Абакумова И.В. Личностный смысл как компонент личностной деёли образовательного процесса // Психология и практика. Ежего, Нй РЕСсийского Психологического Общества. - Ярославль, 1998. - Том 4- Вым 2. - С. 3-5.

2. Абакумова И.В., Фоменко В.Т. Дидактическая поддержкалииихс в образовательном процессе // Инновационная школа. - 1998_№ 2-10). - С. $28-31$.

3. Абакумова И.В. Смысл как научная категория и влияние его концептуальных интерпретаций на теорию образования и обуче $1 /$ / Научная мысль Кавказа. 2002. - № 13(39). - С. 146-151.

4. Абакумова И.В. Обучение и смысл: смыспо бразование в учебном процессе (Психолого-дидактический подход). ОО-ов-на-Дону: изд-во РГУ, 2003. 480 c.

5. Абакумова И.В., Ермаков П.Н., Р Да ова И.А. Смыслоцентризм в педагогике. Новое понимание дидактияеом методов. - Ростов-на-Дону: изд-во РГУ, 2006. - 312 c.

6. Абакумова И.В., Кагеруа Мал.Ч. Смысловые коммуникации в учебном процессе: теория и технполия направленной трансляции смыслов в обучении. Нальчик: Изд-во КВГО.008. - 286 с.

7. Абакумова И.В. СМ. слодидактика. Учебник для магистров педагогики и психологии. - М.. Мзд ३о «КРЕДО», 2008. - 386 с.

8. Абакумо зә М.В., Рудакова И.А. Смыслодидактика в структурно-логических схема ґ. исоное пособие для магистров педагогики и психологии. - М.: изд-во «КРЕД Ж 2009. - 178 с.

9. (4) льдштейн Д.И. Человек как созидатель и носитель социального. - М., 2007. 10 P) Мянцева О.М., Самореализация личности в контексте гуманизации образозания. - М., 2009. 